Available online at https://ejournal.radenintan.ac.id/index.php/ENGEDU

English Education: Jurnal Tadris Bahasa Inggris

pISSN 2086-6003 | elSSN 2580-1449 Vol 12 (1) 2019, 78-96

\title{
TEACHING AND LEARNING NARRATIVE TEXT WRITING THROUGH STORY MAPPING
}

\author{
Nur Latifah ${ }^{1}$, Istiqomah Nur Rahmawati \\ Universitas Nahdlatul Ulama Lampung \\ Email: nurlatifah051@gmail.com
}

\begin{abstract}
This research focused on teaching and learning narrative text writing through story mapping. The objectives of this research were to know and describe the process of teaching and learning narrative writing using story mapping and the teacher and students problems in teaching and learning narrative writing through story mapping. In this research, the writer used descriptive qualitative research method. In collecting the data, the kinds of instruments used by the writers were observation, interview, and questionnaire. In data analysis, the writers used data reduction, data display, and conclusion or verification. The writers found that the teacher's problems in teaching writing through story mapping were the teacher had difficulties to introduce story mapping, giving instruction to create and complete story mapping, many students in the classroo and less time to teach writing. The problems faced by students in learning writing using story mapping were that the students confused and difficult to develop their ideas because they did not have many vocabularies. Furthermore, the students had problems in capitalization, punctuation, grammatical error, and organization. They also needed too much time to finish their writing.
\end{abstract}

Key words: descriptive qualitative research, narrative text, story mapping, writing.

\section{A. INTRODUCTION}

Hyland (2003: 9) said that "writing is a way of sharing personal meaning and writing courses emphasize the power of the individual to construct his or her views on a topic". It means that writing is one of the ways the people do to share information and give their views on some topics. 
In conveying and sharing ideas or opinions, it is good to understand the types of texts used by the writer. There are many kinds of text such as narrative, descriptive, recount, procedure, report, explanation, news item, etc. Siahaan (2008: 73) states "narrative is any written English text in which the writer wants to amuse, entertain people, and to deal with actual or vicarious experience in different ways". It means that narrative text is a text which tells a story of past events to entertain the reader or listener.

One of the techniques that are suitable for students in teaching narrative writing is story mapping. Story mapping is a visual aid, which depicts the settings or of major events and actions of story characters in the narrative text. According to Khalaf (2010: 182) "Story mapping could be used as a visual graphic organizer that draws six elements in narrative text such as setting, characters, the sequence of major events and actions of story characters so that students enable to connect story events and to perceive structure in a story".

Based on the observation conducted at SMPN 3 Pringsewu, the writers found that teaching and learning narrative text writing by using story mapping has been applied there. Based on the result of the interview the English teacher, he said some students found difficulty in writing. The students did not have many vocabularies, it happens because they do not interested and lazy to learn new vocabularies. Moreover, the students also felt confused and difficult to develop their ideas when they want to write. For example, they have ideas in Indonesia language but they felt confused and difficult to write their ideas in the English language. 
As such, the writers wanted to know the teaching and learning process of English subject and want to find information about the causes of the students and the teacher and students problems during teaching and learning process about narrative text writing by using story mapping in SMPN 3 Pringsewu.

\section{Writing}

Mayers (2005: 5) states "writing is an action-a process of discovering and organizing ideas, putting them on a paper, reshaping and revising them." In learning writing, students not only learn about how to make a good writer, but also the students should understand how to make their writing better than before.

In addition, Heaton (1988: 135) says that "writing is complex and sometimes difficult to teach, requiring mastery not only of grammatical devices but also conceptual and judgmental elements". Moreover, according to Urquhart \& Mclver (2005) that "writing is a complex process, and most of the research literature recognizes the difficulty it poses for students. It seems reasonable to expect, then, that the teaching of writing is complex as well". It means that writing is a thinking process in which idea are arranged and combined with a complex knowledge of target language structure, vocabulary, organization, content and language use.

Based on the explanation above, the writer concluded that the activity to express their ideas and thoughts in written form is writing. Moreover, the can improve their other component of languages such as vocabulary, spelling, and grammar so the students not only learn about how to make a good writer.

\section{Narrative Text}


According to Smalley and Ruetten (1986) that "narrative describes a sequence of the events or tell a story, in other word narrative describe an experience. The logical arrangement of idea and sentences in the narrative is chronologicalaccording to time order". Morever, Anderson (1997) states that "narrative is text, which tells a story and in doing so, entertains or informs the reader or listener". It means that narrative is a piece of text that tells a story to inform, amuse, and entertain the reader or listener.

1) Generic Structures

Orientation : the beginning of the story.

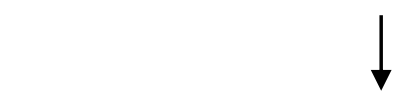

Complication: the problem faced by the main character.

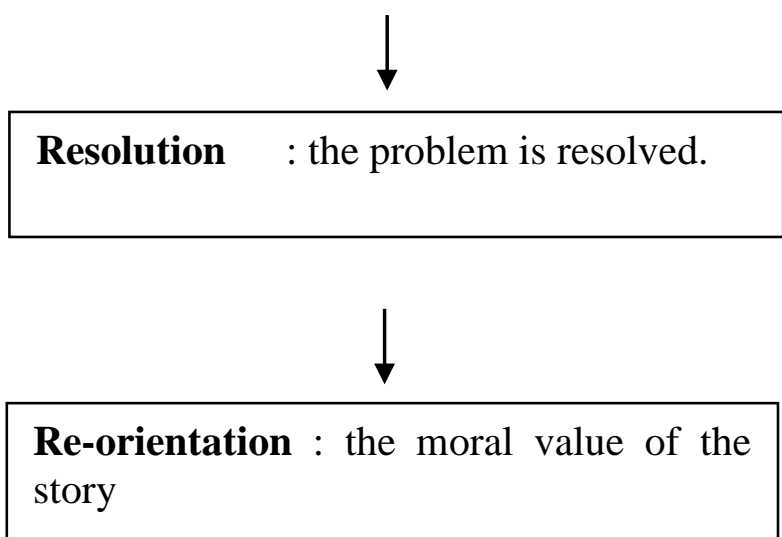

2) Language features 
- Focus on specific and usually individualized participants.

- Focus on material processes.

- Use of relational processes and mental processes

- Use past tense.

According to Harmer (2007: 34), teaching writing is more than just dealing with the feature. It is about helping students to communicate real message inappropriate manner. It means that the teacher should know to make students easily to understand writing well.

However, there are five problems in teaching writing that explained by Almubark (2016 : 15-19) as follows:

a) The topics in textbooks are not attractive

The topics in the textbooks for writing skills are not attractive and persuasive enough which make it quite discouraging to teach writing skills to the students.

b) Credit hours

More credit hours should be added to teaching writing skills so that the problem of writing skills in the classroom can be eradicated.

c) The higher students in the class

The higher students in each class are an obstacle for the teacher to get their teaching goals for teaching writing skills.

d) Teacher competence

Teacher competence in using devices or equipment for learning writing skills will assist the attainment of writing skills in the classrooms.

e) Intensive writing exercise 
Intensive writing exercises and teachers' regular assessment of the material will identify the students' weaknesses in learning English language writing skills.

In teaching writing where its position as a foreign and second language, when the learners begin to write in English, they will face some problems to write based on theory Alfaki (2005: 45-46), some problem as follows:

a. Grammatical problem

The learner has a number of problem in their attempts to write in the second language. Students have problems with subject-verb agreements, pronoun references, and connectors.

b. The problem of sentence structure

To improve the students writing skills, the students must understand the problems with sentence structure so they can not only recognize but write effective sentences.

c. The problem of word choice

A good writing or composition should be consist of an appropriate and varied range of vocabularies used along grammar and varied range of sentence structures.

d. Cognitive problem

1. Punctuation problem

Punctuation can cause a lot of problem in writing. The problem with punctuation is that it makes difficult for the reader to read what you have written. 
2. Capitalization problem

Capital letters are useful for sentence initials, the beginning of important words, in topics, headings. However, learners have a problem in using capitalization properly.

3. Spelling problem

Due to the influence of other languages, Varian pronunciations and other historical reason, the English spelling system which has become inconsistent is complex for students.

4. Content problem

In writing, the students also face problem to exploring ideas and thought to communicate with others.

5. Organization problem

Learners have difficulty in composing of sentence became a paragraph, development topics become a paragraph, structuring the whole discourse and a theme in a discourse.

\section{Story Mapping}

According to Boyle and Scanlon (2009: 208), "story mapping present a basics framework for understanding important elements found in narrative stories". In addition, Schaefer (2001: 47) says that story maps are graphic organizer that helps students recognize the main component of the story. They come in all shapes and sizes. In the early stages of writing development, story maps help students identify the main characters, setting, problem, and solution. It means that the story mapping is a basic framework which can help students to understand elements of the narrative story they are orientation, complication, and resolution. The Advantages of Story Mapping 
The advantages of story mapping as a technique in teaching and learning narrative text by Zygouris and Glass (2004) they are:

"The students can use a story mapping as a pre-reading. Then, the teacher can introduce a book through a complete story map. By deleting some events, students can make predictions about what they think will happen in the story. After that, the students can use their story mapping as notes for oral book reports, in preparing the visualizing presentation and as a prewriting tool in developing their own stories. And the last, the teachers can also use story mapping in writing conferences as a way to help students revise their story writing."

\section{Procedures Story Mapping to Teach Narrative Text Writing}

According to Chamot (1999: 2) the procedures of story mapping in teaching narrative writing it could be explained below:

The first, the students' current procedures and strategies for planning before writing

The second, the teacher can explain the four stages of writing from planning, composing, revising and editing. Then, tell to the students if they will focus on planning their ideas.

After that, the teacher introduces the story mapping as a graphic organizer for planning to write their ideas. The teacher can demonstrate the example of story mapping. 
Next, have the students complete a story mapping for their folktale, students can work in a group to share their ideas and help each other. Moreover, the students' pair exchanges their story mapping.

After the students complete their story mapping, they begin writing their stories and they used story mapping as a guide in their stories

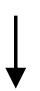

And the last, the teacher review their stories

By looking the explanation of theories above, story mapping as a technique to help the students to understand the elements of the narrative story. Story mapping is a guideline to students write their ideas about narrative story, by using story mapping the students could understand to arrange their ideas about the story before they started to write a narrative story. The students' used story mapping not only expands imagination but also help the students to develop their thoughts and feeling with the theme provided in writing. In addition, in teaching and learning narrative text writing through story mapping many obstacles faced by the teacher and students.

\section{B. RESEARCH METHODOLOGY}

The writer used descriptive qualitative research. According to Miles \& Huberman

(1994: 6) that qualitative research is conducted through an intense and/or 
prolonged contact with "field" or little situation. In the other words, qualitatie research is research which discuss about the reality and happened. These situations are typically "banal" or normal ones, reflective of the everyday life of individuals, groups, societies, and organizations . By this qualitative research, the writer would focus on teaching and learning by using story mapping at the ninth grade of SMPN 3 Pringsewu. In this research, the English teacher and the students of the first semester of the ninth grade in SMPN 3 Pringsewu in academic year 2018/2019 were the subjects. The writer chose IX.7 as the sample of this research.

\section{Data Collecting Technique}

\section{Observation}

Creswell (2005: 213) said that observation is the process of gathering openended, firsthand information by observing people and place at a research site. In this research, the writer as an observer to get the data. The writer observed the process during teaching and learning in the classroom.

\section{Interview}

The interview is interactive of conversation or communication between two people or more people. According to Lodico (2010), there are five types of interview, they are one to one, group interview, structured interview, semistructured interview, unstructured interview. The writer used one to one type interview. The writer interviewed the teacher to know his opinion and problems during teaching and learning process.

3. Questionnaire

Questionnaire is a list of questions given to others who are willing to respond in accordance with user request by Lucido (2010: 137). The writer gave the questionnaire to the students in order to know the further opinions and to know the aspect about the learning process and to confirm the answers given by the 


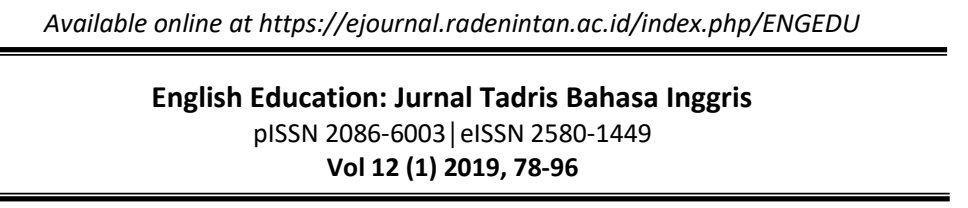

teacher.

Data Analysis

According to Miles and Huberman (1994: 12) theory, in the descriptive qualitative research the data analysis they are: "data reduction, data display, and conclusion drawing or verification."

1) Data Reduction

Data reduction refers to the process of selecting, focusing, simplifying, abstracting and transforming the data that appear in written up field notes or transcriptions.

2) Data Display

Data display is a second component or level in Miles and Huberman model of qualitative data analysis. A display can be an extended piece of text or a diagram, graph, chart, table or matrix that provides a new way of arranging thinking about the more textually embedded data.

3) Conclusion Drawing and Verification

The last step of analyzing the data is conclusion drawing/verification. Conclusion drawing involves stepping back to consider what the analyzed data mean and to assess their implication for the questions at hand.

\section{FINDINGS AND DISCUSSION}

\section{Findings}

Teaching and learning process was done on two meetings in IX.7 class. The material was a narrative text. The writers employed an observation checklist, interviewed, and a questionnaire to know the process of teaching and learning writing using story mapping. However, in conducting the observation the writers 


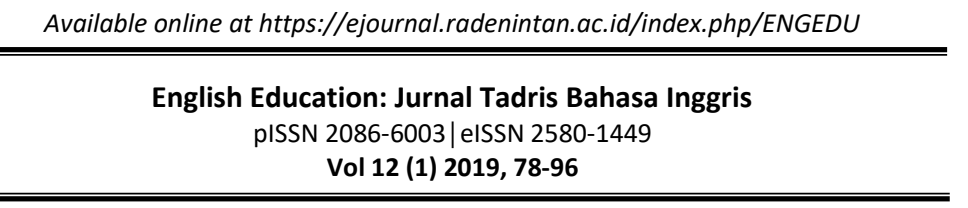

found some problems faced by the teacher and students. The writer assumed that the teaching and learning of narrative writing by using story mapping was not maximal, the teacher did not follow the procedure well, it happened because he skipped the procedure.

The result of the interview also showed that the teacher had some problem in teaching narrative writing using story mapping. The teacher had difficulty with introducing story mapping and instruction the students to create and complete story mapping. Moreover, the teacher had difficulty in manage the class because the higher number of the students so he difficult to keep the attention of many students. The teacher also had difficulty in manage the time because in teaching and learning the teacher and students needed much time.

The result of the questionnaire showed that students had some problem in learning narrative writing using story mapping. The students felt that story mapping could help them in learning narrative writing, but they still had difficulty in learning narrative writing because students still lacked motivation and not less like to learning writing. The students also confused to understand the vocabularies because they had limited vocabulary, their structures were still not good enough because they made mistake in grammar.

\section{Discussion}

The writers assumed that teaching-learning narrative writing by using story mapping was still less effective and maximal. The teacher did not apply all of the procedure of story mapping based on the theory of the experts. Based on the theory of Chamot (1999: 9), there were procedures in applying story mapping in teaching narrative writing. There were write a list idea on the board, explain four 
stages of writing, introducing the story mapping, demonstrate the sample of story mapping, students work in a group to share their ideas and help each other, and then they begin writing their stories, and review their stories.

Based on the result of observation, showed that the process of teaching and learning were in accordance with the theory of Chamot (1999: 9). The teacher has applied almost all the steps in teaching narrative writing through story mapping but some steps that skipped in teaching-learning process, in the first meeting the teacher did not instruct the students to write a whole narrative story after they were finished completely their story mapping, the teacher also did not review and analyzed the result of their story mapping he just instructed the student to collect their task. When the time almost the end, the teacher instructed the students to collect their story mapping but many students not yet finished their story mapping, they said if they difficult to organize their ideas into English. Different from the previous meeting, in second the students wrote a whole narrative story and story mapping as a guideline in writing process but after they finished, the teacher also did not review and analyze the result of their story mapping and the narrative story, the students were just collect to the teacher. Many students did not complete their task on time.

The writer found that the teacher skipped two procedures in the first meeting and one procedure in the second meeting. When the teacher followed all of the procedure of story mapping by the experts well, the teacher must be instructed students to write narrative stories in the first meeting to complete story mapping only, so in the second meeting students were more easily to develop their ideas became a paragraph because students have practiced in the previous meeting and they could finish their story mapping and narrative story on time. The teacher also 
did not analyze and review the result of students task so they did not know the mistakes they made, if the teacher analyzed and reviewed the results of the story mapping and narrative stories of students, they would know their mistakes and not repeat it at the next meeting.

Based on the explanation above, the process of teaching and learning narrative writing by using story mapping was quite good. It could be seen, from the procedure of teaching that was suitable for the procedure based on theory, however there were some steps skipped by the teacher. If the teacher applied all of the procedures in the teaching and learning process, so it would become more optimum and could improve students' abilities, but it did not give the big influence for the teaching and learning process.

In addition, based on the result of interview, the teacher had difficulties to handle the class well it happpened due to many students in the classroom and some of them were busy with their own activity like having a chitchat and it made the class became noisy and crowded, so to resolve this problem he addressed and came to the students to make no more noise in the class. The class conditions were hot, so students felt bored and uncomfortable in the classroom. The teacher also needed much time in teaching and learning writing, it happened because he had difficulties to make the students understood the meaning of the words. The students also were difficult to develop ideas, sometimes they were confused to choose and arrange the words became a paragraph so that it took longer time than usual. It was supported by Almubarak that the problems of teaching writing were the higher number of the class and need much more time. 
The writers found some problems with the English teacher in supporting, stimulating and engaging the students to pay attention when the teacher explained the material. For example, the teacher had difficulties when introduced about story mapping, it happened because many students had difficulty to organize and plan their ideas on the story mapping so the teacher must be explained more about it.

Based on the finding of the teacher problem above, it could be concluded that the theory of Almubarak was appropriate for the real condition in the classroom. The teacher had difficulties to manage class well and less time in teaching and learning process, it was shown that from the interview with the teacher, the other five problems have not occurred during this classroom implementing story mapping.

However, in this research, the writers found some problems faced by the students. The writer found this research was in line to the theory of Alfaki such as the students have problems in grammatical errors, sentence structures, word choice, punctuation, capitalization, spelling, content, and organization. It could be seen in the teaching and learning in the classroom, the students still asked the teacher to know the meaning of the words, it meant that they did not have sufficient vocabularies. They also were confused how to use capital letters, punctuation marks, and word choices. When the teacher spell the words the students wrote an incorrect word, even the students did not arrange well grammatical issue. The students had difficulty in writing a narrative text because they felt difficult and confused to develop their ideas when they have ideas in English.

Based on the explanation of the problems above, it could be concluded that the problems based on the theory happened with the students, even there were more 
problems that happened in the learning narrative writing through story mapping they were grammatical errors, sentence structures, words choice, punctuation, capitalization, spelling, content, and organization. In addition, based on the on the finding of Alfaki journal that the results of students problem in learning writing showed that there were various types of writing problems, mechanical problems, linguistic problems, cognitive problems, psychomotor problems. The findings by Alfaki have similarities and differences with this research. The similarities that the students have problems in mechanical, linguistics, and cognitive problem and the differences that the students in this research did not have psychomotor problems.

\section{CONCLUSION AND SUGGESTION}

\section{Conclusion}

The teaching and learning narrative writing by using story mapping was not optimum, the teacher did not follow the procedure well, it happened because he skipped the procedure. The teaching-learning process was done in two meetings, the classroom atmosphere in teaching and learning narrative writing by using story mapping was noisy, crowded and not conducive. The problems faced by the teacher in teaching narrative writing by using story mapping were the teacher felt difficult to handle the class condition. The teacher had difficulty to manage the time because of its teaching and learning process spared much time. The teacher found difficulties to introduce story mapping clearly until the students understood. Moreover, the teacher had difficulty to instruct the students to create and complete story mapping because. The problem faced by the students in learning narrative writing by using story mapping were most of the students were less like to learn writing because some of them thought that writing was difficult. The students found difficulties in using punctuation and capitalization. They also had difficult to develop their ideas to write the narrative story because the students have 
limited vocabulary and spelling writing. The structures were still not good enough because they made mistake in grammar.

\section{Suggestion}

The teacher should follow the procedure in teaching and learning narrative writing using story mapping well. In addition, he must follow all of the procedure of teaching narrative by using story mapping well by experts. For example, follow the theory by Ann Uhl Chamot. The teacher should manage time as good as possible in order that the implementation of story mapping technique running well and success. He should make the students focus on the teaching-learning process. For example, he must give minus score for the noisy students. So they will not be noisy and the teacher does not have to control the students one by one. It makes the time will run well.

The students should expand their vocabulary that can be easy to write the narrative story. For example, having a consultation using the dictionary and vocabulary books. Moreover, The students should study more about grammar. It can make them easier to making meaning from a sentence. So the students should make meaning from one sentence full not from a word by word. The students should focus on when teaching and learning narrative writing. They should not chitchat with others or be noisy during teaching and learning process. So they can focus to hear and follow the teacher's direction. To further researcher, writer hopes can make the research well and better than in this paper.

\section{E. REFERENCES}

Alfaki, Ibrahim Mohamed. (2005) University Students English Writing Problems: Diagnosis and Remedy, International Journal of English Language Teaching, 


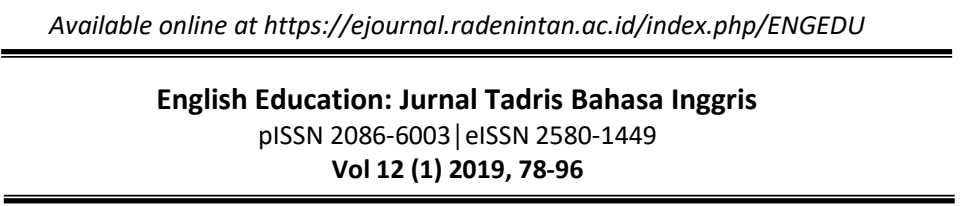

Vol.3, No.3. Retrieved from http://www.eajournals.org/wp-content/uploads /University-Students-English-Writing-Problems-Diagnosis-and-Remedy.pdf.

Almubark , Amin Ali. (2018) Exploring the Problems Faced by the Teachers in Developing English Writing Skills for the Students in Saudi Arabia, International Journal of English Language Teaching, Vol.4, No.10, p. 15-19. Retrieved from www.ejournal.org.

Anderson, Mark and Kathy Anderson. (1997). Text Type in English. South Yara: Macmillan.

Chamot, Anna Uhl, et.al. (1999). The Learning Strategies Hand Book. New York: Longman.

Coe V, Zygouris and C. Glass. (2004) Story Mapping, Florida Department of Education: Reading Strategy of the Month Journal, vol. 2. Retrieved from http://olc.s psd.sk.ca/ De/PD/istr/strats/storymapping/index.

Creswell, John W. (2012). Educational Research. New York: Pearson Educational.

Harmer, Jeremy. (2001). The Practice of English Language Teaching. Harlow: Longman.

Heaton, J.B. (1988). Writing English Language Test. New York: Longman.

Hyland, Ken. (2003). Second Language Writing. New York: Cambridge University Press. 
Ibnian, Salem Saleh Khalaf. (2010). The Effect of Using Story Mapping Technique on Developing Tenth Grade Students' Short Story Writing Skills in EFL, Journal of English Language Teaching, Vol.3, p. 182. Retrieved from http://www.ccsenet.org/journal/index.php/elt/article/view/37027.

Lodico, Marguerite G. (2010). Methods in Educational Research (Second Edition). San Francisco: Jossey-Bass.

Mayers, Alan. (2005). Gateways to Academic Writing: Effective Sentences, Paragraph, and Essays. New York: Longman.

Miles, Matthew B. and A. Michael Huberman. (1994). Qualitative Data Analysis. London: Sage Publications.

Schaefer, Lola M. (2001). Teaching Narrative Writing: The Tools that Work for Every Students. New York: Schoolastic Professional Books.

Siahaan, Sanggam and Kisno Shinoda. (2008). Generic Text Structure. Yogyakarta: Graha Ilmu.

Smalley, Regina L. and Mary K. Ruetten. (1986). Refining Composition Skills Rhetoric And Grammar For Esl Students (Second Edition). New York: Macmillan Publishing Company.

Uruhart, Vicky and Monette Mclver. (2005). Teaching Writing in the Content Areas. Alexandria: Congres Cataloging. 